\title{
PENGARUH METODE SOROGAN TERHADAP KEMAMPUAN MEMBACA KITAB KUNING
}

\author{
Tatang Ruspandi \\ Tatangruspandi1@gmail.com \\ Universitas Islam Al-Ihya Kuningan
}

\begin{abstract}
ABSTRAK
Metode yang digunakan dalam membaca kitab kuning di pesantren sangat beragam sesuai dengan pola pendidikan pesantren yang dipakai. Berbagai metode digunakan dalam pembelajaran demi tercapainya maksud dan tujuan dari pembelajaran. Metode sorogan merupakan salah satu metode dalam memahami isi dari kitab kuning yang dipelajari oleh para santri di Pesantren. Dengan metode sorogan ini santri dapat lebih cepat dapat membaca kitab kuning beserta terjemahannya dalam upaya memahami isi dari kitab kuning.
\end{abstract}

Kata kunci : Sorogan, Kemampuan Membaca, Kitab Kuning

\begin{abstract}
The method used in reading the yellow book in the pesantren varies greatly according to the pesantren education pattern used. Various methods are used in learning to achieve the goals and objectives of learning. The sorogan method is one of the methods in understanding the contents of the yellow book that is studied by students at the Islamic Boarding School. With this sorogan method, students can read the yellow book and its translation more quickly in an effort to understand the contents of the yellow book.
\end{abstract}

Keyword : Sorogan, reading skills, yellow books 


\section{Pendahuluan}

Di dalam dunia pendidikan, baik pendidikan formal maupun non formal tentu membutuhkan sebuah metode/cara yang akan digunakan untuk pembelajaran seharihari. Metode pembelajaran ini harus dipelajari oleh seorang pendidik atau guru dengan harapan proses belajar mengajar bisa berjalan dengan baik dan efektif. Siswa/Santri yang menjadi objek diharapkan lebih bersemangat dalam mengikuti kegiatan belajar di kelas. Namun hal ini tidak semudah membalikan telapak tangan, karena pendidik pada zaman sekarang dituntuk untuk bisa menguasai berbagai macam hal yang berkaita dengan pembelajaran seiring dengan perkembangan zaman yang semakin caggih dan kompleks. Dapat dianggap sebagai modal berharga dalam menanamkan kebiasaan peserta didik melalui proses belajar mengajar (Alhamudin : 2012).

Pesantren yang merupakan pendidikan non formal tidak terlepas dari sebuah metode pembelajaran. Metode pembelajaran yang digunakan di Pesantren bermacammacam sesuai dengan kurikulum yang dipakai ditiap lembaga pesantren itu sendiri. Perkembangan pendidikan islam khusunya di Indonesia merupakan salah satu peran yang dibangun oleh pesantren, arus globalisasi dan modernisasi tidak mempengaruhi eksistensi Pesantren. Hal ini berbeda dengan pendidikan lainnya dikawasan Nusantara. Dimana akibat gelombang pembaharuan dan modernisiasi yang semakin kencang telah menimbulkan perubahan-perubahan yang membawanya keluar dari eksistensi lembaga pendidikan (Azra : 1999).

Metode pembelajaran yang diterapkan di Pesantren diantaranya adalah metode sorogan. Metode ini diharapkan dapat memberikan kemampuan kepada Santri dalam membaca kitab kuning karena santri dituntut untuk memahami isi dari kitab kuning yang dipelajari. Dari permasalahan diatas, muncul pertanyaan apakah metode sorogan dapat mempengaruhi dan meningkatkan kemampuan membaca kitab kuning? Yang mana kitab-kitab tersebut menggunakan bahasa arab yang mana bahasa arab merupakan bahasa yang cukup sulir untuk dipelajari sehingga dibutuhkan keseriusan dalam proses belajar mengajar di pesantren .

Pembahasan 
Pendidikan merupakan salah satu kebutuhan yang harus dilaksanakan oleh setiap orang guna menjadi bekal kehidupan yang akan dating. Dengan pendidikan seseorang akan mendapatkan apa yang diinginkan/dicita-citakan. Tentu hal ini membeutuhkan pengorbanan, baik pengorbanan waktu, biaya, dan sebagainya. Dalam kitab talimul muta'alim disebutkan syarat-syarat mencari ilmu diantaranya yaitu :

1. Waktu yang lama

Didalam menuntut ilmu membutuhkan waktu yang lama. Hal ini mendorong kita agar supaya benar-benar focus apa yang dicita-citakan tercapai. Tidak mungkin menuntut ilmu dengan waktu yang singkat. Sebagaimana pendapat Imam Al-Baihaqi "ilmu tidak akan mungkin didapatkan kecuali dengan meluangkan waktu"

2. Biaya

Biaya merupakan salah satu factor dalam menuntut ilmu. Meskipun tidak menjadi jaminan namun keberadaannya sangat penting. Hal ini dapat dijadikan sandaran agar pencari ilmu tenang dalam menghadapi persoalanpersoalan dalam menuntut ilmu. Didalam kisah diceritakan suatu hari Imam Ahmad melakukan perjalanan jauh keberbagai Negara dengan tujuan mencari ilmu bahkan menjual salah satu kayu penopang rumahnya untuk menuntut ilmu. Ini mengidentikan di dalam menuntut ilmu sesorang harus berkorban waktu bahkan harta yang dimiliknya.

Didalam dunia pesantren ada beberapa metode yang diajarkan dalam proses belajar mengajar, diantaranya metode sorogan. Sorogan adalah proses belajar mengajar yang digunakan oleh santri di Pesantren dengan membawa kitab-kitab yang akan dipelajari di depan para guru. Guru membacakan terlebih dahulu kemudian diikuti oleh para santri dan dibaca berulang-ulang dan berkesinambungan. Kalau diibaratkan kata sorogan dengan pesantren seperti laut dan pantai, dua hal yang tidak dapat dipisahkan. Pembelajaran ini mempunyai filosofis yang mana santri memperoleh perlakuan yang berbeda dari seorang guru atau ustadz. Tingkatan kelas menjadi pedoman keselarasan perlakuan sehingga santri diberi kesempatan atau bisa mempersembahkan atas kemampuannya masing-masing sesuai tingkatannya. 
Didalam metode sorogan, pesantren selalu berusaha semaksimal mungkin agar program dan prioritas dalam pengembangan dan pencapaian sesuai target. Namun hal ini bisa tercapai dengan sumber daya manusia yang ada. Santri senior yang telah menguasai berbagai ilmu dapat dijadikan solusi untuk membantu pelaksanaan sorogan. Ini menjadi Motivasi santri senior untuk mendapatkan dan memberikan ilmu kepada santri junior yang ada dibawahnya. Sebagaimana hadis nabi Yang artinya "Sampaikanlah dariku walaupun hanya satu ayat" Ini mengindetikan kepada kita semua agar bisa menyampaikan ilmu walaupun sedikit dan menjadi tolak ukur agar kegiatan belajar mengajar bukan hanya tentang melaksanakan tugas, tetapi harus memberi manfaat kepada orang lain.

Pondok pesantren yang notabenenya menggunakan metode sorogan merupakan peranan penting dalam meningkatkan pemahaman membaca kitab kuning. Sorogan menurut Arief $(2002,150)$ artinya adalah secara individu dimana seorang santri berhadapan seorang guru, terjadi interaksi saling mengenal diantara keduanya, atau sebuah sistem belajar dimana para santri maju satu persatu untuk membaca dan menguraikan isi kitab di hadapan seorang guru atau kiai. Sebab indicator didalam sorogan ada beberapa tahapan:

1. Tahap awal : mengetahui baris (sakal) dalam membaca kitab kuning

2. Tahap pertengahan : mengetahui arti bacaan kitab kuning

3. Tahap akhir : mengetahui tarkib (susunan bahasa) yang baik dan benar dalam kitab kuning.

Jadi inti dari sorogan selain membaca pemahaman isi dan mengungkapkan bacaan factor utama dalam keberhasilan dan proses pembelajaran metode sorogan.

Kemampuan membaca adalah kecepatan membaca dan pemahaman isi (Dalman:2013) Sedangkan Burns, dkk, mengemukakan kemampuan membaca merupakan sesuatu yang vital dalam suatu masyarakat terpelajar. Kemampuan membaca kitab kuning adalah kemampuan santri dalam membaca membaca kitab sesuai dengan ketapatan penerapan ilmu nahwu dan shorfnya serta kemampuan dalam memahami isi dari kandungan kitab kuning yang dibacanya. Kemampuan membaca 
kitab kuning ini berkembang seiring dengan bertambahnya pemahaman santri terhadap ilmu Nahwu dan Shorfnya.

Kitab kuning merupakan gerbang bagi para pelajar Muslim untuk menggali ilmu-ilmu agama Islam. Literatur ini dipelajari di Indonesia tidak saja di madrasah sejak sebelum era kolonial, tetapi juga dikaji dan dilestarikan di pesantren khusunya pesantren salaf. Kitab kuning meliputi berbagai cabang keilmun islam (Husein : 2015). Kitab kuning ini dikarang soleh salafus shaleh yang tidak diragukan lagi keilmuan dan keshalihannya. Dalam dunia pesantren kitab yang familiar dipelajari dan dijadikan sebagai kurikulum yang wajib dipelajari di pesantren diantaranya dari cabang ilmu fiqih diantaranya safinah, riyadlul badiah, fathul qorib dan yang lainnya, dari cabang ilmu nahwu dan shorf yaitu jurmiah, kailani, alfiyah, dan yang lainnya, dari cabang ubudiyah diantaranya adalah hikam, ihya, tizan daruri, dan lain sebagainya.

Dalam sejarah dan tradisi pesantren, literatur keagamaan kitab kuning tidak saja menjadi pusat orientasi studi, tetapi juga sistem nilai yang membentuk dan mewarnai paham dan praktik keagamaan komunitas pesantren dan masyarakat Muslim sekitarnya. Kitab kuning yang dipelajari ini menjadi bekal bagi santri untuk bekal bagi dirinya dalam mengemban tugasnya sebagai pewaris para ulama dimana para ulama ini merupakan pewaris para Nabi dalam menyebarkan risalah keislaman. 


\section{KESIMPULAN}

Pesantren merupakan lembaga non formal yang mendalami tentang keilmuan agama islam. Dalam dunia pesantren, maju dan mundurnya ditentukan oleh kiayi yang memimpinnya. Dalam pimpinannya kiayi memegang peran penting dalam menentukan pola pendidikan dan gaya pembelajaran, termasuk metode dalam pembelajaran yang digunakan oleh para santri.

Dari sekian banyak metode dalam pembelajaran kitab kuning di pesantren adalah metode membaca kitab kuning dengan metode sorogan. Metode sorogan yaitu guru membaca terlebih dahulu kata perkata beserta artinya kemudian diikuti oleh santri. Metode membaca kitab kuning dengan metode sorogan terbukti dapat meningkatkan kemampuan membaca kitab kuning bagi para santri. Hal ini dinilai lebih efektif dan efisien karena dapat sekaligus meahami isi dari kitab yang dibacanya. 


\section{DAFTAR PUSTAKA}

Alrasyidin. "Pembelajaran Kitab Kuning di Pesantren Musthafawiyah, Madailing Natal" dalam Jurnal of Conteporary Islam and Muslim Societis Vol 1 No. 1 Januari-Juni (2017).

Arief, Armai. 2002. Pengantar Ilmu dan Metodologi Pendidikan Islam. Ciputat: Ciputat Press.

Artikel diakses dari http://jurnal.uinsu.ac.id/index.php/JCIMS/article/view/324 pada tanggal 8 Februari 2020

Dihyatun Masqon, "Dynamic of Pondok Pesantren as Indegenous Islamic Education Centre In ndonesia," dalam Tsaqafah: Jurnal Peradaban Islam, Vol. 7, No. 1 (2011).

Jamaludin, dkk. "Implementasi Metode Sorogan dalam Meningkatkan Kemampuan Membaca Kitab Kuning pada Santri Tingkat Wustho di Pondok Pesantren Al-Muslimun Desa Hegarmanah Kecamatan Sukaluyu Kapbupaten Cianjur Tahun 2019" Prosiding Al Hidayah Pendidikan Agama Islam PISSN: 2654-5829 E-ISSN: 2654-3753. (2019).

Mahrus As'ad, "Pembaruan Pendidikan Islam K.H. Hasyim Asy'ari," dalam saqafah: Jurnal Peradaban Islam, Vol. 8, No. 1, (2012).

Mu'izzudin, dkk. "Implementasi Metode Sorogan dan Bandungan dalam Meningkatkan Kemampuan Membaca Kitab Kuning". Dalam Jurnal Pendidikan Agama Islam. p-ISSN 2407-4313, e-ISSN : 2654-3575, Vol 6 No. 1 (2019).

Mustofa. "Kitab Kuning sebagai Literatur Keislaman dalam Konteks Perpustakaan Pesantren" dalam Jurnal Tibanndaru Vol. 2 No. 2. (2018).

Syamsul Huda, "Kultus Kiai: Sketsa Tradisi Pesantren," dalam Teosofi: Jurnal Tasawuf dan Pemikiran Islam, Vol. 1, No. 1, (2011).

Tasi'ul Jabbar, dkk. "Upaya Kiai dalam Meningkatkan Kemampuan Membaca Kitab Kuning" 